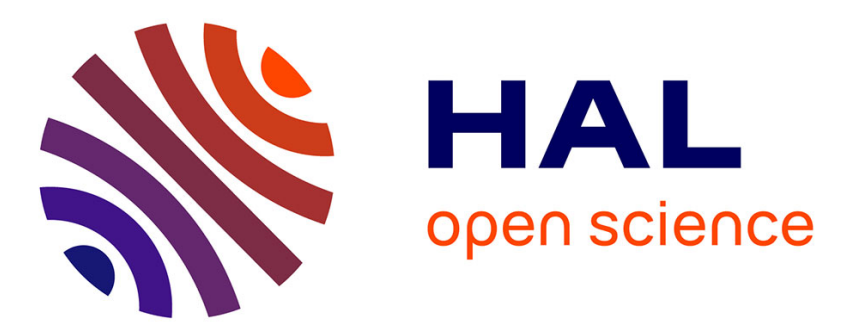

\title{
Mycorrhization, growth and nutrition of Pinus halepensis seedlings fertilized with different doses and sources of nitrogen
}

Gisela Diaz, Catalina Carrillo, Mario Honrubia

\section{To cite this version:}

Gisela Diaz, Catalina Carrillo, Mario Honrubia. Mycorrhization, growth and nutrition of Pinus halepensis seedlings fertilized with different doses and sources of nitrogen. Annals of Forest Science, 2010, 67 (4), 10.1051/forest/2009125 . hal-00883597

\section{HAL Id: hal-00883597 https://hal.science/hal-00883597}

Submitted on 1 Jan 2010

HAL is a multi-disciplinary open access archive for the deposit and dissemination of scientific research documents, whether they are published or not. The documents may come from teaching and research institutions in France or abroad, or from public or private research centers.
L'archive ouverte pluridisciplinaire $\mathbf{H A L}$, est destinée au dépôt et à la diffusion de documents scientifiques de niveau recherche, publiés ou non, émanant des établissements d'enseignement et de recherche français ou étrangers, des laboratoires publics ou privés. 


\title{
Mycorrhization, growth and nutrition of Pinus halepensis seedlings fertilized with different doses and sources of nitrogen
}

\author{
Gisela DIAZ $^{1 *}$, Catalina CARRILlO ${ }^{2}$, Mario HONRUBIA $^{2}$ \\ ${ }^{1}$ Depto. Biología Aplicada, Botánica, Univ. Miguel Hernández, Avda. Universidad s/n, 03202, Elche, Alicante, Spain \\ ${ }^{2}$ Depto. Biología Vegetal, Botánica, Univ. Murcia, Campus Espinardo, 30100, Murcia, Spain
}

(Received 22 June 2009; accepted 9 September 2009)

Keywords:

mycorrhiza /

nitrogen /

Pinus halepensis /

fertilization /

nursery

\author{
Mots-clés : \\ mycorhize / \\ azote / \\ Pinus halepensis / \\ fertilisation / \\ pépinière
}

\begin{abstract}
- Although fertilization is commonly used in nurseries, the effects of high level of nitrogen on Pinus halepensis mycorrhization are still unknown.

- The effect of fertilization at different $\mathrm{N}$ levels (low-LN: $35 \mathrm{mg} / \mathrm{plant}$; medium-MN: $60 \mathrm{mg} / \mathrm{plant}$; high-HN: $120 \mathrm{mg} / \mathrm{plant}$ ), differing $\mathrm{N}$ sources (ammonium- $\left(\mathrm{NH}_{4}\right)_{2} \mathrm{SO}_{4}$; nitrate- $\mathrm{HNO}_{3}$; ammonium+nitrate- $\mathrm{NH}_{4} \mathrm{NO}_{3}$ ) and inoculation with Pisolithus tinctorius and Lactarius deliciosus on the mycorrhization, growth and nutrient status of $P$. halepensis has been studied.

- P. tinctorius 3SR showed higher mycorrhizal ability (100\% of mycorrhizal seedlings) than L. deliciosus (nearer to 50\%). The application of increasing doses of $\mathrm{N}$ resulted in a significant reduction of mycorrhizal seedlings but no differences were observed between $\mathrm{NH}_{4}$ and $\mathrm{NO}_{3}$ as $\mathrm{N}$ source at the $60 \mathrm{mg} \mathrm{N} /$ plant dose applied. The effects of fertilization on growth were mainly observed in uninoculated plants. The use of $\mathrm{NH}_{4}$ increased growth in non-mycorrhized plants. Nutrient status was similar in all cases except for $\mathrm{K}$ concentration, which was higher in plants mycorrhized with P. tinctorius. Interactions between inoculation and fertilization were found, mycorrhizal effects appearing only at LN fertilization.

- It is advisable to avoid high doses of $\mathrm{N}$ fertilization in order to produce mycorrhizal $P$. halepensis seedlings.
\end{abstract}

Résumé - Mycorhization, croissance et nutrition de semis de Pinus halepensis fertilisés avec différentes doses et sources d'azote.

- Bien que la fertilisation soit couramment utilisée dans les pépinières, les effets d'un niveau élevé d'azote sur la mycorhization chez Pinus halepensis sont encore inconnus.

- L'effet de la fertilisation à différents niveaux d'azote (LN bas : $35 \mathrm{mg} / \mathrm{plant;}$ MN moyen : $60 \mathrm{mg} /$ plant ; HN élevé : $120 \mathrm{mg} / \mathrm{plant}$ ), avec différentes sources d'azote (ammonium- $\left(\mathrm{NH}_{4}\right)_{2} \mathrm{SO}_{4}$; nitrate- $\mathrm{HNO}_{3}$; ammonium+nitrate- $\mathrm{NH}_{4} \mathrm{NO}_{3}$ ) et inoculation avec Pisolithus tinctorius et Lactarius deliciosus a été étudié pour la mycorhization, la croissance et l'état nutritionnel du Pinus halepensis. - P. tinctorius 3SR a montré une aptitude plus élevée à la mycorhization (100\% des plants mycorhizés) que L. deliciosus (proche de $50 \%$ ). L'application de doses croissantes d'azote a entraîné une réduction significative des semis mycorhizés mais aucune différence n'a été observée entre $\mathrm{NH}_{4}$ et $\mathrm{NO}_{3}$ comme source de $\mathrm{N}$ à une dose appliquée de $60 \mathrm{mg} \mathrm{N} /$ plant. Les effets de la fertilisation sur la croissance ont été principalement observés chez les plants non inoculés. L'utilisation de $\mathrm{NH}_{4}$ augmente la croissance chez les plants non mycorhizés. L'état nutritionnel a été similaire dans tous les cas sauf pour la concentration de $\mathrm{K}$, qui est plus élevée chez les plants mycorhizés par $P$. tinctorius. Des interactions entre inoculation et fertilisation ont été trouvées, les effets mycorhiziens n'apparaissant qu'à des fertilisations LN.

- Il est conseillé d'éviter de fortes doses de fertilisation azotée pour produire des plants de $P$. halepensis mycorhizés.

\footnotetext{
* Corresponding author: gdiaz@umh.es
} 


\section{INTRODUCTION}

Several crop-related factors intervene in the production process of quality forest plants at the commercial level of which fertilization is one of the most critical and, if suitably adjusted, will produce plants with an optimum nutritional status to be subsequently transplanted in the field. Nitrogen $(\mathrm{N})$ is the nutrient mostly consumed by plants and it largely limits the growth of plants growing in containers (Landis et al., 1989). Fertilization programmes are initially based on the amount of $\mathrm{N}$ provided as it forms part of many vital compounds for plant development (i.e., chlorophyll, amino acids and proteins) and is essential for the development of healthy leaves.

It is generally accepted that inoculation with mycorrhizal fungi is an advisable practice for producing high quality nursery seedlings. Mycorrhizal symbiosis may improve the quality of seedlings by increasing plant growth and/or their physiological attributes (Brundrett et al., 1996). These benefits relate to the uptake of water and nutrients, enhanced root enzyme activity, a more efficient use of water, a higher photosynthesis rate or greater protection against pathogens. Then, mycorrhized seedlings are expected to overcome outplanting stress in comparison with non-mycorrhizal plants (Luo et al., 2009; $\mathrm{Zhu}$ et al., 2008). This is especially important as far as $\mathrm{Pi}$ nus halepensis Miller is concerned, one of the most planted pine species in the Mediterranean basin. This species plays a critical role in the restoration of degraded lands under adverse climate and soil conditions. Several studies report the beneficial effect of mycorrhizal inoculation on field performance in P. halepensis (Díaz et al., 2004; Parladé et al., 2004; Querejeta et al., 1998; Rincón et al., 2007a; Roldan et al., 1996).

Nonetheless, the $\mathrm{N}$ fertilization regime may influence mycorrhizae development. High $\mathrm{N}$ levels are commonly used in nurseries to produce container-grown plants. However, a good number of studies have shown that high $\mathrm{N}$ concentrations in substrates inhibit ectomycorrhizae development (Arnebrant, 1994; Brunner and Brodbeck, 2001; Holopainen and Heinonen-Tanski, 1993; Wallander and Nylund, 1991) whereas a moderate deficiency of $\mathrm{N}$ favours mycorrhization.

Not all mycorrhizal fungi species show the same sensitivity to $\mathrm{N}$ fertilization; some species are highly sensitive to excessive nitrogen, others colonize nitrogen-rich substrates (Wallander, 1994; Wallander and Nylund, 1992).

Another important aspect of $\mathrm{N}$ fertilization is the source used since the composition of the fertilizer determines whether $\mathrm{N}$ is assimilated and its effect on the plant. Plants can absorb $\mathrm{N}$ as ammonium $\left(\mathrm{NH}_{4}\right)$ or nitrate $\left(\mathrm{NO}_{3}\right)$, and balanced formulae of both $\mathrm{N}$ sources are usually employed (Landis et al., 1989). Some authors have observed how mycorrhizal development is more affected when $\mathrm{NO}_{3}$ rather than $\mathrm{NH}_{4}$ is used as $\mathrm{N}$ source (Väre, 1989). In other cases, $\mathrm{NH}_{4}$ seems more harmful than $\mathrm{NO}_{3}$ (Termoshuizen and Ket, 1991; Wallander and Nylund, 1991).

Therefore, it is important to adjust $\mathrm{N}$ fertilization when producing quality mycorrhizal plants in nurseries. Although former works have studied the influence of fertilization on the mycorrhization of several forest species, no information about $P$. halepensis is available. The objective of this work was to determine the effect of $\mathrm{N}$ fertilization in relation to both the source and dose used on plant growth, nutrient status and mycorrhization of $P$. halepensis inoculated with three strains of ectomycorrhizal fungi and to asses the effect of mycorrhizae on plant growth attributes.

\section{MATERIALS AND METHODS}

\subsection{Plant material}

The container used was a Poliforest ${ }^{\circledR}$, Poliex, Spain tray made of expanded polystyrene with 25 individual cells filled with a $350 \mathrm{cc}$, plastic, removable and openable pot. It has vertical ribs to prevent spiralling and an open base to allow for drainage. The potting substrate used was unsterilized Sphagnum peat VAPO ${ }^{\circledR} \mathrm{BO}$, Finland ( $\mathrm{pH}$ 5.3). $P$. halepensis seeds collected from Maestrazgo, Los Serranos, Teruel, Spain were surface disinfected by shaking in $30 \mathrm{vol} \mathrm{H}_{2} \mathrm{O}_{2}$ for $20 \mathrm{~min}$., then rinsed in distilled water and sown in the container (3-4 seeds per cell) on February. The containers were placed in the glasshouse $\left(T^{a}\right.$ ranged from 6 to $25^{\circ} \mathrm{C}$ ). Germination occurred within 20-30 d. After germination, seedlings were cleared to one per cell. Plants were moved outdoors and grown from March to November under natural climatic and day/night conditions, shaded by a mesh (40\% radiation reduction) in the summer.

\subsection{Fungal inoculum and inoculation}

The inoculated fungal species were Pisolithus tinctorius (Pers.) Coker \& Couch (strains 3SR, collected at Uceda, Guadalajara, Spain under a Quercus rotundifolia-P. halepensis stand and Mx, collected at Tlaxcala, Mexico under P. oocarpa) and Lactarius deliciosus (L. ex Fr.) Gray (strain LDF5, collected at Valencia, Spain under a P. halepensis stand).

Isolations of mycorrhizal strains were done with explants from basidioma tissue on modified Melin-Norkrans medium (MMN) (Marx, 1969) for P. tinctorius, and according to the procedure described in Díaz et al. (2009) for L. deliciosus. They were transferred to fresh media every three months. Reference cultures were deposited at the culture collection of Laboratory of Mycology-Mycorrhizas of the University of Murcia, Spain.

Inoculum of $P$. tinctorius was produced using $1 \mathrm{~L}$ flasks filled with a sterilized $\left(120^{\circ} \mathrm{C}, 20 \mathrm{~min}\right)$ mixture of peat and vermiculite $(1: 4 \mathrm{v} / \mathrm{v})$ moistened with MMN liquid medium. Then, flasks were inoculated with several plugs of mycelium growing on MMN solid agar plates, and incubated at $23{ }^{\circ} \mathrm{C}$ in the dark for approximately 8 weeks. Inoculum of $L$. deliciosus was prepared by growing mycelia in flasks with MMN liquid medium and incubation at $23{ }^{\circ} \mathrm{C}$ in the dark for 4-8 weeks due to the poor development of the mycelium on solid substrate. Inocula were checked for viability on MMN agar plates before use.

Seedlings were inoculated in the spring, three months after emergence. According to previous experiments (unpublished data), $25 \mathrm{~mL} /$ plant of peat-vermiculite inoculum were placed onto the root surface for $P$. tinctorius treatments, and $10 \mathrm{~mL} /$ plant of liquid inoculum were injected in the root zone for the L. deliciosus treatment. Control plants remained uninoculated. 


\subsection{Experimental design}

Two experiments were done independently at the forest nursery from Centro Nacional de Mejora Genética Forestal El Serranillo, of the Spanish Ministerio de Medio Ambiente y Medio Rural y Marino, at Guadalajara, Spain.

Experiment 1: A factorial experiment was set up to check the effect of two factors: (1) application of different $\mathrm{N}$ fertilization levels (low-LN, medium-MN and high-HN, corresponding to 35, 60 and $120 \mathrm{mg} \mathrm{N} /$ plant, respectively) and (2) inoculation with mycorrhizal fungi (P. tinctorius 3SR, P. tinctorius $\mathrm{Mx}, L$. deliciosus, uninoculated control) on mycorrhizal development and plant growth. There were 100 replicates per treatment.

All the plants were fertilized every two weeks from April to September except August with Peter's Professional ${ }^{\circledR}$, Scotts, Spain fertilizer with different N-P-K formulations suitable for plant development at each plant growth phase: Conifer Starter (7-40-17) at germination (twice), Conifer Grower (20-7-19) during plant growth (6 times) and Conifer Finisher (4-25-35) at hardening (twice). Plants with the $\mathrm{MN}$ and $\mathrm{HN}$ levels were supplemented with $10 \mathrm{~mL} /$ plant of a solution of $\mathrm{NH}_{4} \mathrm{NO}_{3}$ at the adequate concentration. This supplement was applied 6 times coinciding with fertilization at the plant growth phase. The total amount of macronutrients received by seedlings with the LN, MN and HN treatments was 35-27-61, 60-27-61 and 120-27$61 \mathrm{mg} \mathrm{NPK} /$ plant, respectively.

Experiment 2: A factorial experiment was set up to check the effect of two factors: (1) application of different $\mathrm{N}$ sources $\left(\mathrm{NH}_{4}, \mathrm{NO}_{3}\right.$, $\mathrm{NH}_{4}+\mathrm{NO}_{3}$ ) and (2) inoculation with mycorrhizal fungi (P. tinctorius $3 \mathrm{SR}, L$. deliciosus, uninoculated control) on mycorrhizal development and plant growth. There were 100 seedlings per treatment. Plants were fertilized with Peter's Professional ${ }^{\circledR}$ fertilizer with the LN treatment schedule of Experiment $1 . \mathrm{N}$ source treatments were supplied as a solution of $21 \%\left(\mathrm{NH}_{4}\right)_{2} \mathrm{SO}_{4}, 59 \% \mathrm{HNO}_{3}$ and $45 \%$ $\mathrm{NH}_{4} \mathrm{NO}_{3}$. These supplements were applied 6 times coinciding with fertilization at the plant growth phase. The total amount of macronutrients received by seedlings was 60-27-61 mg NPK/plant.

\subsection{Measurements and statistical analysis}

All the seedlings were assessed for mycorrhizal development at five months post-inoculation. Two parameters were determined: (1) percentage of mycorrhizal seedlings (ratio between seedlings that became mycorrhizal by the inoculated fungi and total inoculated seedlings for each treatment) and (2) mycorrhizal colonization index (percentage of mycorrhizal colonization by the inoculated fungi in each root system determined by a non-destructive, visuallydetermined observation and expressed as an index ranging from 0 to 5 (0: $0 \%, 1: 1-20 \%, 2: 21-40 \%, 3: 41-60 \%, 4: 61-80 \%, 5: 81-100 \%$ of the root system colonized by mycorrhiza) (Abourouh, 1996).

All the seedlings were measured for height and root collar diameter. Twenty-five seedlings were randomly selected from each treatment. Growing media was removed from the roots. Plant fractions (shoots, roots) were separated, washed, dried at $60{ }^{\circ} \mathrm{C}$ for $48 \mathrm{~h}$, and weighed. Needles were analyzed for nutrient contents: $\mathrm{N}$ by the Kjeldahl method, P by colorimetry (Olsen, 1954) and K by atomic absorption spectroscopy.

Data were analyzed with the software package SPSS 10.0 for Windows. The percentages of mycorrhizal seedlings for each treatment were analyzed by contingency tables. Mycorrhizal colonization, growth and nutrition data were analyzed by a two-way ANOVA
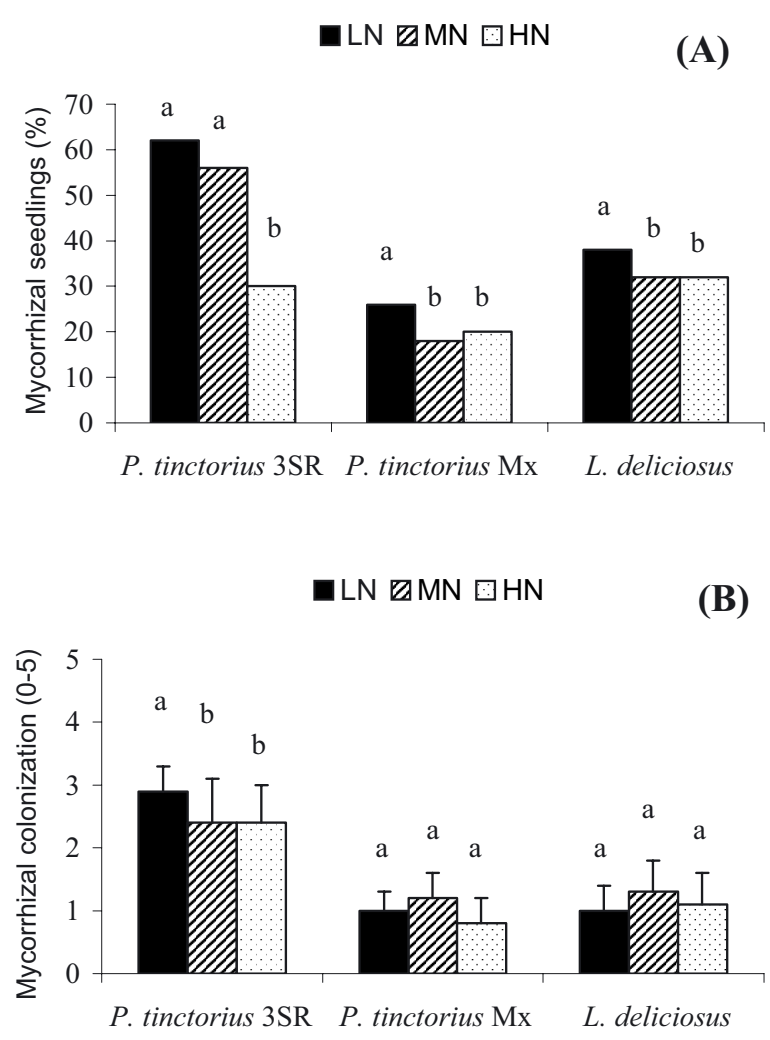

Figure 1. Percentages of mycorrhizal seedlings (A) and mycorrhizal colonization index (B) on $P$. halepensis inoculated with three ectomycorrhizal fungi under different $\mathrm{N}$ fertilization levels (low-LN: 35 mg/plant, medium-MN: 60 mg/plant, high-HN: 120 mg/plant). For each inoculation treatment, different letters indicate significant differences (Contingency tables for percentage of mycorrhizal seedlings, Duncan's test, $p \leq 0.05$ for mycorrhizal colonization).

to see the effects of the factors. Significant differences among treatments were determined by Duncan's multiple range test. The mycorrhizal colonization data were arc-sin transformed before performing ANOVAs to achieve normality.

\section{RESULTS}

\subsection{Mycorrhiza formation}

The three fungal strains inoculated were able to form mycorrhizas on $P$. halepensis, but showed a different mycorrhizal capacity. The autochthonous $P$. tinctorius 3 SR was much more effective (with almost $100 \%$ of mycorrhizal seedlings) than P. tinctorius from Mexico (18-25\% of mycorrhizal seedlings). L. deliciosus formed around $50 \%$ of mycorrhizal seedlings. However, the percentage of mycorrhizal seedlings obtained was affected by the amount and source of $\mathrm{N}$ applied.

Applying increasing doses of $\mathrm{N}$ significantly reduced mycorrhizal seedlings when compared with the values obtained with low doses. Whereas mycorrhiza formation by P. tinctorius 3SR was only affected at the highest $\mathrm{N}$ dose, $P$. tinctorius $\mathrm{Mx}$ and L. deliciosus were affected at the MN and $\mathrm{HN}$ doses (Fig. 1A). Mycorrhizal colonization was not affected by fertilization treatments, except for $P$. tinctorius 3SR which achieved 

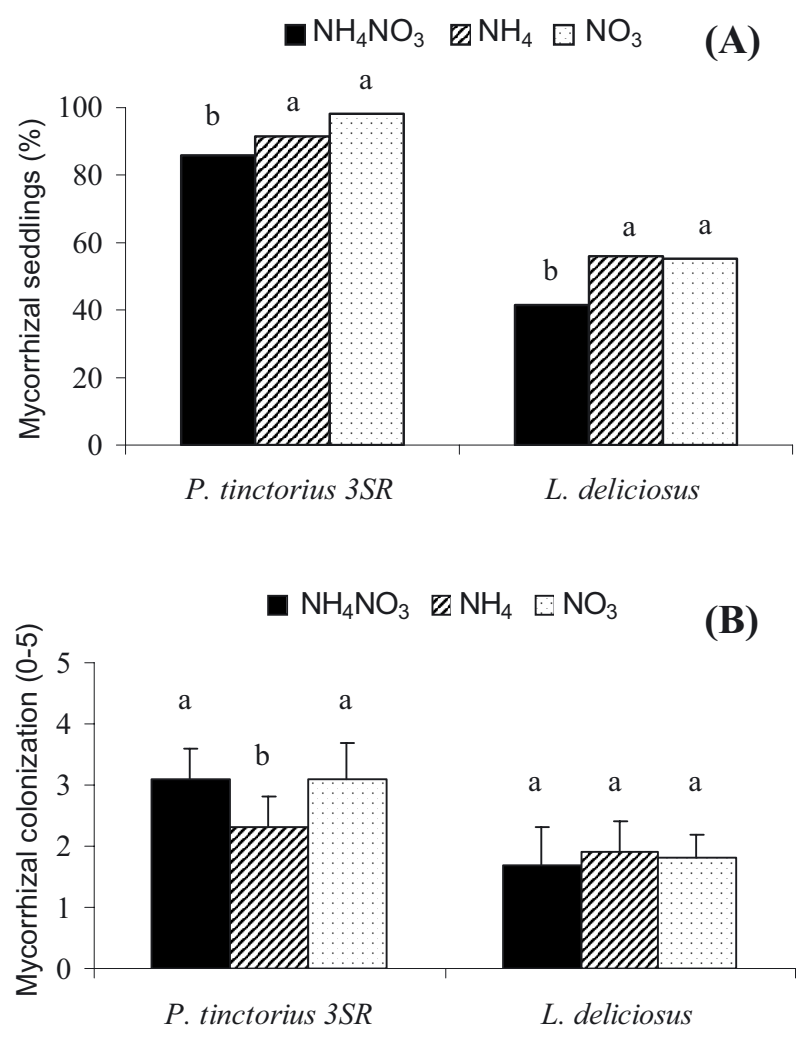

Figure 2. Percentages of mycorrhizal seedlings (A) and mycorrhizal colonization index (B) on $P$. halepensis inoculated with three ectomycorrhizal fungi under different $\mathrm{N}$ fertilization sources (ammonium nitrate- $\mathrm{NH}_{4} \mathrm{NO}_{3}$, ammonium- $\left(\mathrm{NH}_{4}\right)_{2} \mathrm{SO}_{4}$, nitrate- $\left.\mathrm{HNO}_{3}\right)$. For each inoculation treatment, different letters indicate significant differences (Contingency tables for percentage of mycorrhizal seedlings, Duncan's test, $p \leq 0.05$ for mycorrhizal colonization).

a higher mycorrhizal colonization at the LN level than at the MN or HN levels (Fig. 1B).

The mycorrhizal seedlings rates obtained with $\mathrm{NH}_{4} \mathrm{NO}_{3}$ were lower than those obtained with $\mathrm{NH}_{4}$ or $\mathrm{NO}_{3}$ as $\mathrm{N}$ source (Fig. 2A). Mycorrhizal colonization was slightly lower for P. tinctorius 3SR with $\mathrm{NH}_{4}$, and was similar for $L$. deliciosus with the three $\mathrm{N}$ sources (Fig. 2B).

Spontaneous mycorrhizae formed by other fungi such as Rhizopogon or Suillus were rarely observed. Indeed, mycelia and strands of Telephora terrestis appeared at the bottom part of root systems at the end of the experiment but apparently they did not prevent colonization by the inoculated fungi.

\subsection{Plant growth and nutrition}

Inoculation and $\mathrm{N}$ dose factors had a significant effect on almost all the plant growth parameters. It is important to note that significant interactions between inoculation and $\mathrm{N}$ dose factors were found for all plant growth parameters (Tab. I).

The effect of fertilization on plant functional attributes varied under the different inoculation treatments. Fertilization with increasing doses of $\mathrm{N}$ significantly increased the shoot dry weight of uninoculated plants and plants inoculated with $P$. tinctorius $\mathrm{Mx}$, and the shoot/root ratio of $L$. deliciosus treatments. With $P$. tinctorius 3SR however, the plant growth parameters were higher with the lowest $\mathrm{N}$ dose. The comparison of inoculation treatments within each fertilization level shows that plants mycorrhized with $P$. tinctorius were higher and had a larger diameter than uninoculated plants with lower $\mathrm{N}$ doses (Tab. I). No significant differences were observed among treatments for nutrient concentrations; only the $\mathrm{K}$ concentration was affected by $\mathrm{N}$ dose and inoculation factors (Tab. II).

The effects of inoculation and $\mathrm{N}$ source factors on plant growth are shown in Table III. The inoculation factor was only significant for root dry weight, whereas the $\mathrm{N}$ source significantly influenced height, diameter, branches and root dry weight. Significant interactions were found for height and shoot dry weight. The growth parameters slightly increased when the $\mathrm{N}$ source was $\mathrm{NH}_{4}$, especially with uninoculated plants. Height and the number of branches were higher in P. tinctorius $3 \mathrm{SR}$ seedlings fertilized with $\mathrm{NH}_{4}$. No differences were observed for $\mathrm{N}$ and $\mathrm{P}$ concentrations among treatments; inoculation and $\mathrm{N}$ source were significant only for $\mathrm{K}$ (Tab. IV).

\section{DISCUSSION}

\subsection{Effect of $\mathbf{N}$ fertilization on mycorrhizal development}

The high mycorrhizal capacity shown by $P$. tinctorius 3 SR makes this strain a good candidate for nursery inoculations with $P$. halepensis. $P$. tinctorius has been widely used for inoculating several conifer species in nurseries with varying success rates (Brundrett et al., 1996; Marx, 1981; Rincón et al., 2005). The effectiveness of fungus $L$. deliciosus was only around $50 \%$, which is in line with other previous reports for this fungus (Gonzalez-Ochoa et al., 2003; Parladé et al., 2003). This low mycorrhizal capacity may not be attributed to the type of inoculum used, since inoculum as a mycelial suspension in a liquid carrier has been previously shown to be most effective for this strain (Díaz et al., 2009). Thus it would probably be necessary to optimize some cultural or environmental factors to achieve higher mycorrhizal rates in nurseries.

Increasing $\mathrm{N}$ fertilization negatively affected the mycorrhizal capacity of the fungi used, which is in agreement with other studies done on different plant and fungal species (Arnebrant, 1994; Holopainen and Heinonen-Tanski, 1993). An excess $\mathrm{N}$ input has been demonstrated to reduce the fungal biomass (Wallander and Nylund, 1991; 1992). According to the carbohydrate theory, high $\mathrm{N}$ availability implies consumption of carbohydrate to reduce $\mathrm{NO}_{3}$ to $\mathrm{NH}_{4}$ inside the roots. This process reduces the pool of sugar concentration in the roots to reach levels that are too low to initiate infection. So $\mathrm{N}$ assimilation acts like a carbon sink (Nehls, 2004).

In relation to $\mathrm{N}$ sources used, the number of mycorrhizal plants was similar with $\mathrm{NH}_{4}$ and $\mathrm{NO}_{3}$. It is interesting to point out that the data obtained with the three treatmentes were comparable with those obtained at the same $\mathrm{N}$ dose in Experiment 1. Previous reports have documented 


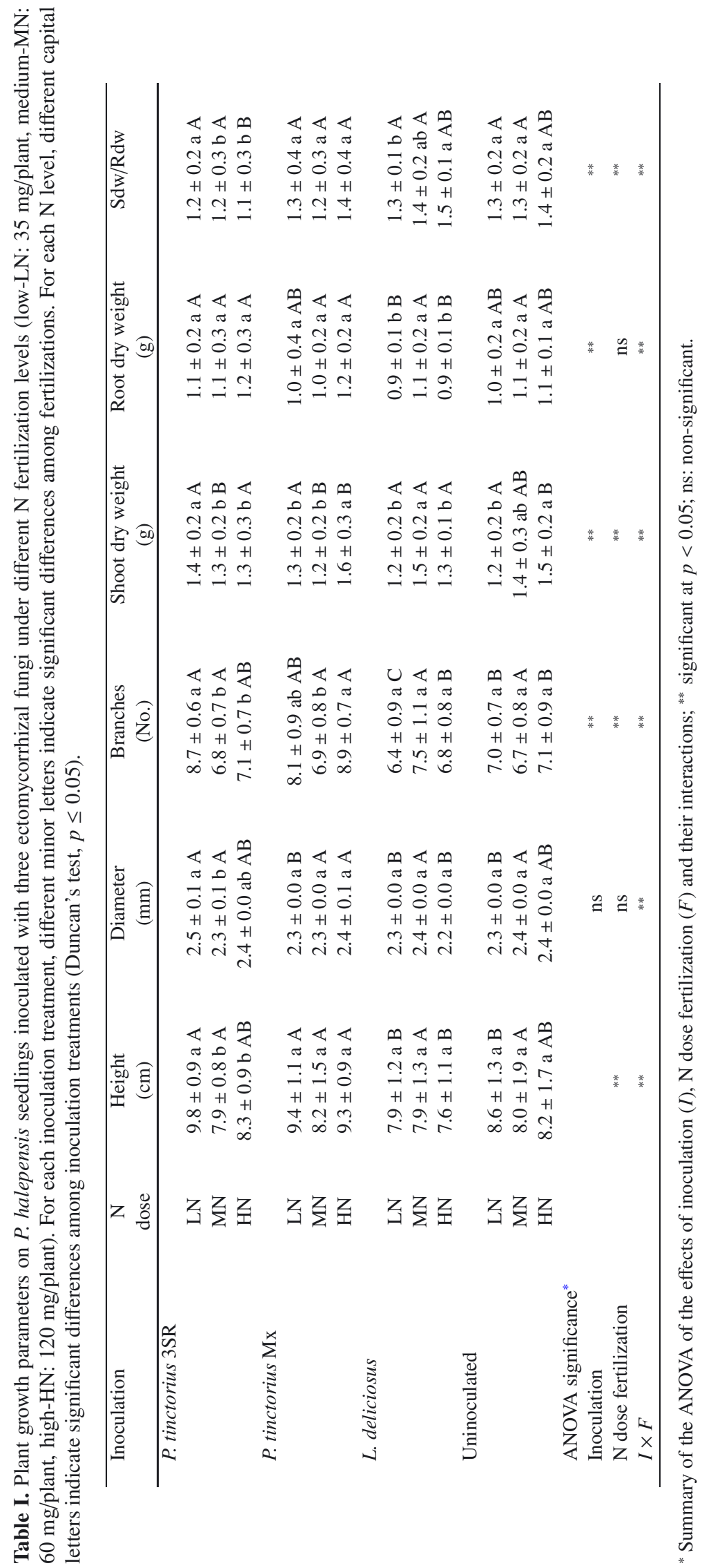


Table II. Nutrient concentration in needles of $P$. halepensis seedlings inoculated with three ectomycorrhizal fungi under different $\mathrm{N}$ fertilization levels (low-LN: $35 \mathrm{mg} /$ plant, medium-MN: $60 \mathrm{mg} /$ plant, high-HN: $120 \mathrm{mg} / \mathrm{plant}$ ). For each inoculation treatment, different letters indicate significant differences (Duncan's test, $p \leq 0.05$ ).

\begin{tabular}{|c|c|c|c|c|}
\hline Inoculation & $\begin{array}{c}\mathrm{N} \\
\text { dose }\end{array}$ & $\begin{array}{c}\mathrm{N} \\
(\%) \\
\end{array}$ & $\begin{array}{c}\mathrm{P} \\
(\%) \\
\end{array}$ & $\begin{array}{c}\mathrm{K} \\
(\%) \\
\end{array}$ \\
\hline \multicolumn{5}{|l|}{ P. tinctorius 3SR } \\
\hline & $\mathrm{LN}$ & $1.11 \pm 0.04 \mathrm{a}$ & $0.14 \pm 0.05 \mathrm{a}$ & $0.83 \pm 0.05 \mathrm{a}$ \\
\hline & $\mathrm{MN}$ & $0.93 \pm 0.03 \mathrm{a}$ & $0.13 \pm 0.08 \mathrm{a}$ & $0.81 \pm 0.03 \mathrm{ab}$ \\
\hline & $\mathrm{HN}$ & $1.00 \pm 0.04 \mathrm{a}$ & $0.10 \pm 0.03 \mathrm{a}$ & $0.70 \pm 0.06 b$ \\
\hline \multicolumn{5}{|l|}{ P. tinctorius $\mathrm{Mx}$} \\
\hline & $\mathrm{LN}$ & $1.05 \pm 0.02 \mathrm{a}$ & $0.13 \pm 0.04 \mathrm{a}$ & $0.84 \pm 0.03 \mathrm{a}$ \\
\hline & $\mathrm{MN}$ & $0.98 \pm 0.01 \mathrm{a}$ & $0.11 \pm 0.03 \mathrm{a}$ & $0.67 \pm 0.08 \mathrm{a}$ \\
\hline & $\mathrm{HN}$ & $1.10 \pm 0.04 \mathrm{a}$ & $0.12 \pm 0.04 \mathrm{a}$ & $0.70 \pm 0.04 \mathrm{a}$ \\
\hline \multicolumn{5}{|l|}{ L. deliciosus } \\
\hline & $\mathrm{LN}$ & $0.99 \pm 0.01 \mathrm{a}$ & $0.11 \pm 0.02 \mathrm{a}$ & $0.71 \pm 0.06 \mathrm{a}$ \\
\hline & $\mathrm{MN}$ & $0.92 \pm 0.02 \mathrm{a}$ & $0.11 \pm 0.01 \mathrm{a}$ & $0.61 \pm 0.05 \mathrm{a}$ \\
\hline & $\mathrm{HN}$ & $1.03 \pm 0.03 \mathrm{a}$ & $0.12 \pm 0.01 \mathrm{a}$ & $0.65 \pm 0.05 \mathrm{a}$ \\
\hline \multicolumn{5}{|l|}{ Uninoculated } \\
\hline & $\mathrm{LN}$ & $1.04 \pm 0.01 \mathrm{a}$ & $0.13 \pm 0.02 \mathrm{a}$ & $0.78 \pm 0.07 \mathrm{a}$ \\
\hline & $\mathrm{MN}$ & $0.95 \pm 0.02 \mathrm{a}$ & $0.12 \pm 0.01 \mathrm{a}$ & $0.69 \pm 0.04 \mathrm{a}$ \\
\hline & $\mathrm{HN}$ & $1.07 \pm 0.02 \mathrm{a}$ & $0.11 \pm 0.02 \mathrm{a}$ & $0.71 \pm 0.03 \mathrm{a}$ \\
\hline \multicolumn{5}{|c|}{ ANOVA significance* } \\
\hline Inoculation & & ns & $\mathrm{ns}$ & ** \\
\hline $\mathrm{N}$ dose fertilization & & ns & $\mathrm{ns}$ & ** \\
\hline$I \times F$ & & ns & $\mathrm{ns}$ & ns \\
\hline
\end{tabular}

* Summary of the ANOVA of the effects of inoculation $(I), \mathrm{N}$ dose fertilization $(F)$ and their interactions; ${ }^{* *}$ significant at $p<0.05$; ns: non-significant.

that ectomycorrhizal fungi prefer $\mathrm{NH}_{4}$ to $\mathrm{NO}_{3}$ (Guidot, 2005; Rangel-Castro et al., 2002) as the latter has a strong inhibitory effect on mycorrhizal development (Väre, 1989). Other authors found that $\mathrm{NH}_{4}$ affected mycorrhizae more negatively than $\mathrm{NO}_{3}$ (Termoshuizen and Ket, 1991; Wallander and Nylund, 1991). It is likely that the amount applied (60 mg $\mathrm{N} /$ plant) is not enough to detect inhibitory effects. Therefore, the $\mathrm{N}$ dose factor appears to be more critical than the $\mathrm{N}$ source factor.

Although the use of $\mathrm{NH}_{4} \mathrm{NO}_{3}$ reduced mycorrhiza formation, it maintained sufficient high levels of mycorrhization. Therefore, it may be considered a compatible fertilizer with nursery inoculation if the recommendations to use balanced formulae of both $\mathrm{N}$ sources are followed (Domínguez, 1997; Landis, 1989).

The mycorrhizal colonization of $P$. tinctorius 3SR inside the roots is affected by $\mathrm{N}$, unlike the other fungi used. Previously, $P$. tinctorius was found to be sensitive to high $\mathrm{N}$ fertilization (Rincón et al., 2007b). Tolerance to $\mathrm{N}$ may correspond to a distinct enzymatic activity that implies a different substrate exploitation method (Taniguchi et al., 2008) and could be one of the factors regulating the distribution of ECM fungi in poor or rich $\mathrm{N}$ forests. Wallander (1994) suggested that species which rapidly absorb $\mathrm{N}$ and swiftly transfer it to the host plant may be more sensitive to excess $\mathrm{N}$ because they tend to use large amounts of carbohydrates while assimilat- ing this element. This, in turn, reduces the available amount of carbohydrates for fungal growth.

\subsection{Effect of $\mathbf{N}$ fertilization on plant growth and nutrition}

The general tendency of fertilization to increase shoot weight and the shoot/root $(\mathrm{S} / \mathrm{R})$ ratio has been observed with some treatments of this study. This response has been previously documented for several plant species (Canham et al., 1996), which also include Mediterranean species (Oliet et al., 2004; Villar-Salvador et al., 2004; 2005). The S/R ratio is interesting although controversial for field survival, particularly when availability of water is restricted. Plants with a high S/R ratio transpire more than plants with a low $S / R$ ratio, which may increase their drought vulnerability to soil water shortage after outplanting. However, there is evidence that $P$. halepensis plants with a high $\mathrm{S} / \mathrm{R}$ ratio display greater field survival in some experiments than small seedlings with low $\mathrm{S} / \mathrm{R}$ rates (Oliet et al., 2009). As high $\mathrm{N}$ fertilization is generally recommended for seedling production for afforestation purposes (Puertolas et al., 2003), it is advisable to check sufficiently high $\mathrm{N}$ concentrations for plant growth that enable adequate mycorrhization.

Plant growth attributes increased more with $\mathrm{NH}_{4}$ than with $\mathrm{NH}_{4} \mathrm{NO}_{3}$. Under the typical high humidity and substrate 


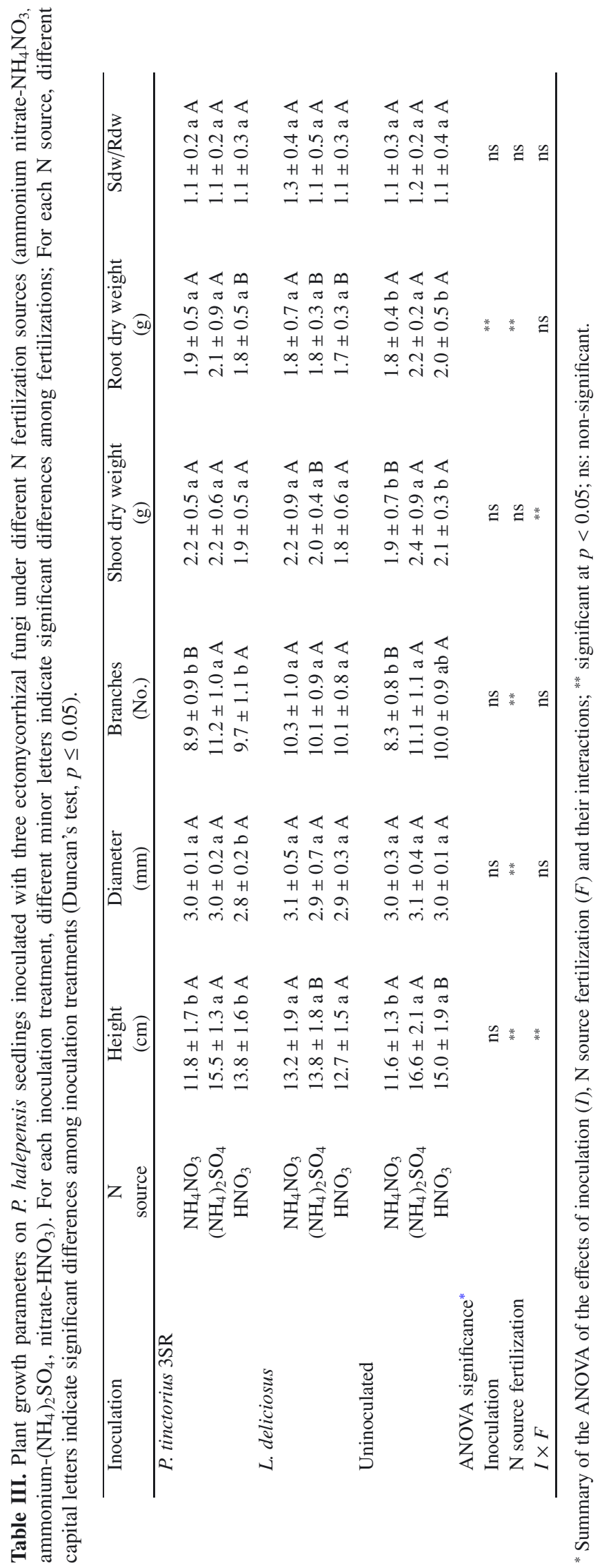


Table IV. Nutrient concentration in needles of $P$. halepensis seedlings inoculated with three ectomycorrhizal fungi under different $\mathrm{N}$ fertilisation sources (ammonium nitrate- $\mathrm{NH}_{4} \mathrm{NO}_{3}$, ammonium- $\left(\mathrm{NH}_{4}\right)_{2} \mathrm{SO}_{4}$, nitrate- $\left.\mathrm{HNO}_{3}\right)$. For each inoculation treatment, different letters indicate significant differences (Duncan's test, $p \leq 0.05$ ).

\begin{tabular}{|c|c|c|c|c|}
\hline Inoculation & $\begin{array}{c}\mathrm{N} \\
\text { source }\end{array}$ & $\begin{array}{c}\mathrm{N} \\
(\%)\end{array}$ & $\begin{array}{c}\mathrm{P} \\
(\%)\end{array}$ & $\begin{array}{c}\mathrm{K} \\
(\%)\end{array}$ \\
\hline \multicolumn{5}{|l|}{ P. tinctorius 3SR } \\
\hline & $\mathrm{NH}_{4} \mathrm{NO}_{3}$ & $1.00 \pm 0.04 \mathrm{a}$ & $0.20 \pm 0.03 \mathrm{a}$ & $1.07 \pm 0.08 \mathrm{a}$ \\
\hline & $\left(\mathrm{NH}_{4}\right)_{2} \mathrm{SO}_{4}$ & $0.90 \pm 0.03 a$ & $0.18 \pm 0.02 \mathrm{a}$ & $0.96 \pm 0.04 \mathrm{a}$ \\
\hline & $\mathrm{HNO}_{3}$ & $0.96 \pm 0.03 \mathrm{a}$ & $0.24 \pm 0.01 \mathrm{a}$ & $1.21 \pm 0.08 \mathrm{a}$ \\
\hline \multicolumn{5}{|l|}{ L. deliciosus } \\
\hline & $\mathrm{NH}_{4} \mathrm{NO}_{3}$ & $0.96 \pm 0.02 \mathrm{a}$ & $0.22 \pm 0.01 \mathrm{a}$ & $1.14 \pm 0.03 \mathrm{a}$ \\
\hline & $\left(\mathrm{NH}_{4}\right)_{2} \mathrm{SO}_{4}$ & $0.95 \pm 0.05 \mathrm{a}$ & $0.22 \pm 0.01 \mathrm{a}$ & $0.86 \pm 0.05 b$ \\
\hline & $\mathrm{HNO}_{3}$ & $0.91 \pm 0.10 \mathrm{a}$ & $0.21 \pm 0.03 \mathrm{a}$ & $0.88 \pm 0.07 b$ \\
\hline \multicolumn{5}{|l|}{ Uninoculated } \\
\hline & $\mathrm{NH}_{4} \mathrm{NO}_{3}$ & $0.78 \pm 0.04 \mathrm{a}$ & $0.19 \pm 0.05 \mathrm{a}$ & $1.09 \pm 0.07 \mathrm{a}$ \\
\hline & $\left(\mathrm{NH}_{4}\right)_{2} \mathrm{SO}_{4}$ & $0.89 \pm 0.02 \mathrm{a}$ & $0.18 \pm 0.03 \mathrm{a}$ & $0.84 \pm 0.02 b$ \\
\hline & $\mathrm{HNO}_{3}$ & $0.93 \pm 0.03 \mathrm{a}$ & $0.2 \pm 0.03 \mathrm{a}$ & $0.9 \pm 0.05 a b$ \\
\hline \multicolumn{5}{|l|}{ ANOVA significance* } \\
\hline Inoculation & & ns & ns & ** \\
\hline $\mathrm{N}$ source fertilization & & ns & ns & ** \\
\hline$I \times F$ & & ns & ns & ns \\
\hline
\end{tabular}

${ }^{*}$ Summary of the ANOVA of the effects of inoculation $(I)$, N source fertilization $(F)$ and their interactions; ${ }^{* *}$ significant at $p<0.05$; ns: non-significant.

porosity nursery conditions, $\mathrm{NH}_{4} \mathrm{NO}_{3}$ will partially be lost through leaching, whereas $\mathrm{NH}_{4}$ forms leach very little. This may account for the improved assimilation of $\mathrm{NH}_{4}$ as certain parameters indicate. However, the use of $\mathrm{NH}_{4}$ as an exclusive $\mathrm{N}$ source as a fertilizer is not recommended for containergrown forest plants.

The $\mathrm{N}$ and $\mathrm{P}$ concentration was similar in all cases irrespectively of the treatment applied, and their levels remain within the range of values that are considered acceptable for container-grown $P$. halepensis (Puértolas et al., 2003). Although $\mathrm{N}$ fertilization has been shown to increase tissue $\mathrm{N}$ concentration (Oliet et al., 2004; Villar-Salvador et al., 2005), this effect was not observed in our study. It is likely due to the differences in the $\mathrm{N}$ amounts applied not being large enough to be reflected in shoot content. Indeed, shoot growth seems to increase in parallel to that of $\mathrm{N}$ uptake, thus producing a dilution effect. The total $\mathrm{N}$ content per plant in uninoculated seedlings was significantly higher at the highest dose (1.57 mg N/plant) than at the low $(1.29 \mathrm{mg} \mathrm{N} /$ plant $)$ or medium ( $1.30 \mathrm{mg} \mathrm{N} / \mathrm{plant})$ dose.

\subsection{Effect of inoculation on plant growth and nutrition}

Inoculation with mycorrhizal fungi did not produce generalized but sporadic effects on plant morphological attributes, which depended on the $\mathrm{N}$ fertilization dose and source. Negative inoculation $\mathrm{x}$ fertilization interactions were found, so mycorrhizal effects appeared only at low fertilization, whereas high fertilization eliminated these effects. Interactive effects between fertilization and mycorrhization are frequent (Hilszanska et al., 2008; Parladé et al., 2003; Rincón et al., 2005; 2007b; Smith and Read, 1997) and are attributed to the large amount of carbohydrates that the fungus requires to establish symbiosis (Dosskey et al., 1991). This justifies the detrimental effects of the mycorrhiza observed, particularly on the $P$. tinctorius 3 SR strain which reached the highest root colonization levels.

Growth data are reflected in the nutrient data and only effects on $\mathrm{K}$ concentration were observed. The $\mathrm{K}$ concentration of plants mycorrhized with $P$. tinctorius was higher than in uninoculated plants. The $\mathrm{K}$ concentration in tissues relates to the vitality of the nursery plant and resistance to fungalrelated diseases. It plays a key role in osmotic adjustment, in regulating the stomatic aperture and contributes to reduce losses caused by transpiration (Landis, 1989). Therefore, mycorrhization with this fungus may be advantageous for the plant as it is likely to be more resistant to drought, thus ensuring a higher post-transplant survival rate.

In this work, $\mathrm{N}$ fertilization affected the amount and scope of mycorrhizae with $P$. tinctorius and $L$. deliciosus in $P$. halepensis. The influence of mycorrhizae on seedling growth was modest and depended on the dose and source of $\mathrm{N}$. Therefore, it is advisable to adjust $\mathrm{N}$ fertilization, avoiding too high doses, in order to produce mycorrhizal seedlings to be outplanted.

Acknowledgements: This study was supported by the agreement between ICONA-Instituto para la conservación de la Naturaleza, Spain and the University of Murcia. We are grateful to J.L. Peñuelas, P. Villar and S. Domínguez from Centro Nacional de Mejora Genética y Forestal El Serranillo, Guadalajara, Spain, for their helpful comments and suggestions. We are also grateful to Helen Warburton for her help with the English translation.

\section{REFERENCES}

Abourouh M., 1996. Les évaluations quantitatives des mycorhizes en pépinière et sur le terrain. Cah. Options méditerr. 20: 51-61. 
Arnebrant K., 1994. Nitrogen amendments reduce the growth of extramatrical ectomycorrhizal mycelium. Mycorrhiza 5: 7-15.

Brunner I. and Brodbeck S., 2001. Response of mycorrhizal Norway spruce seedlings to various nitrogen loads and sources. Environ. Pollut. 114: 223-233.

Brundrett M., Bougher N., Dell B., Grove T., and Malajczuk N., 1996. Working with mycorrhizas in forestry and agriculture, ACIAR Monograph 32, Camberra, Australia, 374 p.

Canham C.D., Berkowitz A.R., Kelly V.R., Lovett G.M., Ollinger S.F., and Schnurr J., 1996. Biomass allocation and multiple resource limitation in tree seedlings. Can. J. For. Res. 26: 1521-1530.

Díaz G., Carrillo C., and Honrubia M., 2009. Production of Pinus halepensis seedlings inoculated with the edible fungus Lactarius deliciosus under nursey conditions. New For. 38: 215-227.

Díaz G., Gutiérrez A., and Honrubia M., 2004. Utilización de micorrización controlada en la reforestación de un suelo agrícola con pino carrasco. Cuad. Soc. Esp. Cien. For. 17: 151-155.

Dominguez A., 1997. Tratado de Fertilización. Mundi-Prensa, Madrid, $613 \mathrm{p}$.

Doskey M.G., Boersman L., and Linderman R.G., 1991. Role for the photosynthate demand of ectomycorrhizas in response of Douglasfir seedlings to drying soil. New Phytol. 117: 327-334.

González-Ochoa A.I., de las Heras J., Torres P., and Sánchez-Gómez E., 2003. Mycorrhization of Pinus halepensis Mill. and Pinus pinaster Aiton seedlings in two commercial nurseries. Ann. For. Sci. 60: $43-48$.

Guidot A., Verner A.C., Debaud J.C., and Marmeisse R., 2005. Intraspecific variation in use of different organic nitrogen sources by the ectomycorrhizal fungus Hebeloma cylindrosporum. Mycorrhiza 15: 167-177.

Hilszczanska D., Malecka M., and Sierota Z., 2008. Changes in nitrogen level and mycorrhizal structure of Scots pine seedlings inoculated with Thelephora terrestris. Ann. For. Sci. 65: 409.

Holopainen T. and Heinonen-Tanski H., 1993. Effects of different nitrogen sources on the growth of Scots pine seedlings on the ultraestructure and development of their mycorrhizae. Can. J. For. Res. 23: 362372

Landis T.D., Tinus R.W., McDonald S.E., and Barnett J.P., 1989. The container tree nursery manual, vol. 4, Mineral nutrients and fertilization. Agric. Hanbook 674, USDA Forest Service, Washington D.C., $120 \mathrm{p}$.

Luo Z., Li K., Jiang X., and Polle A., 2009. Ectomycorrhizal fungus (Paxillus involutus) and hydrogel affect performance of Populus euphratica exposed to drought stress. Ann. For. Sci. 66: 106.

Marx D.H., 1969. The influence of ectotrophic mycorrhizal fungi on the resistance of pine roots to pathogenic infections. I. Antagonism of mycorrhizal fungi to root pathogenic fungi and soil bacteria. Phytopathology 59: 153-163.

Marx D.H., 1981. Variability in ectomycorrhizal development and growth among isolates of Pisolithus tinctorius as affected by source, age and reisolation. Can J. For. Sci. 11: 168-174.

Ne'eman G. and Trabaud L., 2000. Ecology, biogeography and management of Pinus halepensis and P. brutia forest ecosystems in the Mediterranean Basin. Backhuys Publishers, The Netherlands, 407 p.

Nehls U., 2004. Carbohydrates and nitrogen: Nutrients and signals in ectomycorrhizs. In: Varma A., Abbott L., Werner D., and Hampp R. (Eds.), Plant surface microbiology, Springer Verlag, Berlin Heidelberg, Germany, pp. 377-392.

Oliet J., Planelles R., Segura M.L., Artero F., and Jacobs D.F., 2004. Mineral nutrition and growth of containerized Pinus halepensis seedlings under controlled-release fertilizer. Sci. Hort. 103: 113-129.

Oliet J., Planelles R., Artero F., Valverde R., Jacobs D.F., and Segura M.L., 2009. Field performance of Pinus halepensis planted in Mediterranean arid conditions: relative influence of seedling morphology and mineral nutrition. New For. 37: 313-331.

Olsen S.R., Cole C.V., Watanabe F.S., and Dean L.A., 1954. Estimation of available phosphorus in soils by extraction with sodium bicarbonate. USDA Circ. 939.
Parladé J., Luque J., Pera J., and Rincón A. 2004. Field performance of Pinus pinea and Pinus halepensis seedlings inoculated with Rhizopogon spp. and out-planted in formerly arable land. Ann. For. Sci. 61: 504-514.

Parladé J., Pera J., and Luque J., 2003. Evaluation of mycelial inocula of edible Lactarius species for the production of Pinus pinaster and $P$. sylvestris mycorrhizal seedlings under greenhouse conditions. Mycorrhiza 14: 171-176.

Puértolas J., Gil. L., and Pardos J.A., 2003. Effects of nutritional status and seedling size on field performance of Pinus halepensis planted on former arable land in the Mediterranean basin. Forestry 76: 159168.

Querejeta J.I., Roldán A., Albadalejo J., and Castillo V., 1998. The role of mycorrhizae, site preparation, and organic amendment in the afforestation of a semi-arid mediterranean site with Pinus halepensis. For. Sci. 44: 203-211.

Rangel-Castro J.I., Danell E., and Taylor A.F., 2002. Use of different nitrogen sources by the edible ectomycorrhizal mushroom Cantharellus cibarius. Mycorrhiza 12: 131-137.

Rincón A., Parladé J., and Pera J., 2005. Effects of ectomycorrhizal inoculation and the type of substrate on mycorrhization, growth and nutrition of containerised Pinus pinea L. seedlings produced in a commercial nursery. Ann. For. Sci. 62: 1-6.

Rincón A., de Felipe M.R., and Fernández Pascual M., 2007a. Inoculation of Pinus halepensis Miller with selected ectomycorrhizal fungi improves seedling establishemnt 2 years after planting in a degraded gypsum soil. Mycorrhiza 18: 23-32

Rincón A., Parladé J., and Pera J., 2007b. Influence of the fertilisation method in controlled ectomycorrhizal inoculation of two Mediterranean pines. Ann. For. Sci. 64: 577-783

Roldán A., Querejeta J.I., Albadalejo J., and Castillo V. 1996. Growth response of Pinus halepensis to inoculation with Pisolithus arhizus in a terraced rangeland amended with urban refuse. Plant Soil 179: $35-43$.

Smith S.E. and Read D.J., 1997. Mycorrhizal symbiosis. Academic Press, Cambridge, $605 \mathrm{p}$.

Taniguchi T., Kataoka R., and Futai K., 2008. Plant growth and nutrition in pine (Pinus thunbergii) seedlings and dehydrogenase and phosphatase activity of ectomycorrhizal root tips inoculated with seven individual ectomycorrhizal fungal species at high and low nitrogen conditions. Soil. Biol. Biochem. 40: 1235-1243.

Termoshuizen A.J. and Ket P.C., 1991. Effects of $\mathrm{NH}_{4}$ and nitrate on mycorrhizal seedlings of Pinus sylvestris. Eur. J. For. Pathol. 21: 404413.

Väre H., 1989. Effect of nitrogen on the growth of Suillus variegatus on mycorrhizal and non-mycorrhizal Pinus sylvestris seedlings. Aquilo. Ser. Bot. 26: 19-24.

Villar-Salvador P., Planelles R., Enríquez E., and Peñuelas Rubira J., 2004. Nursery cultivation regimes, plant functional attributes, and field performance relatioships in the Mediterranean oak Quercus ilex L. For. Ecol. Manage. 196: 257-266.

Villar-Salvador P., Puértolas J., Peñuelas J.L., and Planelles R., 2005. Effect of nitrogen ferillization in the nursery on the drought and frost resistance of Mediterranean forest species. Investig. Agrar. Sist. Recur. For. 14: 408-418.

Wallander H., 1994. A new hypothesis to explain allocation of dry matter between mycorrhizal fungi and pine seedlings in relation to nutrient supply. Plant Soil 168: 243-248.

Wallander H. and Nylund J.E., 1991. Effects of excess nitrogen on carbohydrate concentration and mycorrhizae development of Pinus sylvestris L. seedlings. New Phytol. 119: 405-441.

Wallander H. and Nylund J.E., 1992. Effects of excess nitrogen and phosphorous starvation on the extramatrical mycelium of ectomycorrhizas of Pinus sylvestris L. New Phytol. 120: 495-503.

Zhu J., Li F., Xu M., Kang H., and Wu X., 2008. The role of ectomycorrhizal fungi in alleviating pine decline in semiarid sandy soil of northern China: an experimental approach. Ann. For. Sci. 65: 304. 